\title{
Religiösa \\ marknadsstrukturer, \\ religiös pluralism och \\ sekulariseringsprocesser
}

\author{
EVA M HAMBERG
}

Många av de europeiska länderna framstår i ett globalt perspektiv som starkt sekulariserade, och Sverige brukar av religionssociologer ofta beskrivas som ett av världens mest sekulariserade länder. Olika hypoteser har framförts om sekulariseringens orsaker. I denna artikel diskuteras betydelsen av religiösa marknadsstrukturer som bidragande orsaker till sekulariseringsprocesser, med särskild tonvikt på förekomsten eller frånvaron av religiös pluralism. Avslutningsvis diskuteras kortfattat, som exempel på sekulariseringens samhällskonsekvenser, de problem som vissa invandrare och flyktingar kan möta i det sekulariserade svenska samhället.

Stora delar av Europa, framför allt Västeuropa, har under det senaste seklet genomgått betydande förändringar på religionens område genom omfattande sekulariserings-

Eva M Hamberg, fil. dr. i ekonomisk historia, teol. dr. och docent i religionssociologi och professor i migrationsvetenskap vid Lunds universitet. processer. Många av de europeiska länderna framstår nu i ett internationellt perspektiv som mycket sekulariserade, både $i$ den meningen att de kristna kyrkorna har förlorat en stor del av sitt tidigare inflytande och i den meningen att relativt låga andelar av befolkningen numera omfattar en traditionell kristen tro och regelbun- 
det deltar i kyrkornas gudstjänstliv. Inte minst gäller detta för det svenska samhället. Sverige brukar ofta beskrivas som ett av världens allra mest sekulariserade länder. För majoriteten av svenskarna har den traditionella kyrkoorienterade religionen inte längre någon betydelse i det dagliga livet, även om drygt sju svenskar av tio fortfarande är medlemmar i Svenska kyrkan. Detta innebär dock inte att svenskarna i allmänhet skulle vara ointresserade av religiösa eller andliga frågor. Tvärtom visar religionssociologiska undersökningar att många tror på en transcendent makt eller kraft och på någon form av liv efter döden. Men det intresse för religion eller andlighet som fortfarande finns hos många svenskar tar sig sällan uttryck i deltagande i kyrkornas verksamhet. Det är som regel inte hos kyrkorna som man söker svar på sina existentiella frågor.

Den utveckling mot ett alltmer sekulariserat samhälle, som kännetecknat Sverige och en stor del av de övriga europeiska länderna under det gångna seklet, har av många religionssociologiska forskare tolkats som tecken på att religionen är på väg att förlora sin betydelse i det moderna samhället. Faktorer som industrialisering, urbanisering, höjd utbildningsnivå, höjd levnadsstandard och ökad social trygghet etc. har ansetts bidra till att religionen i takt med den moderna samhällsutvecklingen kan förväntas få en alltmer marginell roll. Den sekularisering som kännetecknar många av de europeiska länderna har setts som en följd av dessa länders utveckling mot alltmer moderna samhällen. Modernisering och sekularisering har antagits gå hand i hand, och denna hypotes har ibland betecknats som "sekulariseringsteorin". ${ }^{1}$

Ett problem med denna hypotes om religionens minskande betydelse i moderna samhällen är emellertid att det främst är de (väst)europeiska länderna som har kännetecknats av en fortgående sekularisering. I ett globalt perspektiv kan inte samma utveckling iakttas. Framför allt USA är ett tydligt exempel på ett modernt samhälle, där religionen har en mycket stor betydelse i människors dagliga liv. Medan exempelvis den långsiktiga trenden för gudstjänstdeltagandet i Europa varit nedåtgående, har utvecklingen i USA länge varit den motsatta: under de senaste två seklerna har den religiöst aktiva andelen av befolkningen uppvisat en långsiktigt stigande trend. Samtidigt som vissa forskare (inte minst i Europa) har uppfattat den europeiska utvecklingen som den "normala»i moderna samhällen, och därmed sett det amerikanska mönstret som avvikande från det normala, har andra forskare (inte minst i USA) haft motsatt uppfattning: den europeiska situationen har uppfattats avvika från ett mer normalt mönster. Man har därför velat finna orsaker till att den religiösa utvecklingen i USA varit annorlunda än utvecklingen i flertalet av de europeiska länderna. Ett viktigt forskningsområde som under de senaste decennierna har vuxit fram inom främst amerikansk religionssociologi har därför gällt religiösa "marknadsstruktu-

1 För en mer utförlig diskussion om sekulariseringens innebörd och orsaker och en jämförande analys av två sekulariseringsteoretiska teser, se Thorleif Petterssons artikel i detta temanummer av Socialvetenskaplig Tidskrift. 
rer«. Frågor om religiös pluralism, utbud och efterfrågan på "religiösa marknader" och betydelsen av rationella val har kommit att tilldra sig forskares intresse.

\section{Religiösa marknader och religiös pluralism}

I vetenskapliga studier av sekulariseringsprocesser har tyngdpunkten ofta legat på efterfrågan: man har varit intresserad av faktorer som skulle kunna förklara varför människors intresse för religion förefaller att ha minskat i de moderna västeuropeiska samhällena. Under senare år har emellertid forskare, inte minst i USA, också börjat intressera sig för utbudets inverkan på religiöst deltagande. Man har exempelvis menat att en viktig förklaring till skillnaderna mellan USA och de västeuropeiska länderna i fråga om religiös utveckling står att finna i det religiösa utbudets olika karaktär (t.ex. Finke \& Stark 1992, Hamberg \& Pettersson 1994, 2002, Stark \& Finke 2000, Stark \& Iannaccone 1994).

Framhållandet av det religiösa utbudets betydelse förefaller ibland att ha lett till missuppfattningen att de forskare som intresserat sig för utbudets effekter skulle mena att sekulariseringsprocesser inte alls påverkas av förändringar i efterfrågan, utan enbart sammanhänger med det religiösa utbudet. Det torde emellertid vara få, om ens någon, forskare som skulle hävda att en ökning av det religiösa utbudet i ett samhälle alltid leder till ökad religiös aktivitet, oavsett vilken efterfrågan som finns, eller att ett ökat utbud automatiskt leder till ökad efterfrågan. Liksom på andra mark- nader kan det emellertid även på religiösa "marknader» finnas så kallade marknadsimperfektioner, exempelvis genom att ett visst samfund givits en särskilt gynnad ställning och därigenom kan dominera marknaden. I situationer då ett samfund har en monopolliknande ställning, behöver det religiösa utbudet inte vara sådant att det svarar mot den faktiska efterfrågan, utan det kan finnas en latent efterfrågan som inte tillfredställs av det existerande utbudet. Människors deltagande i religiös verksamhet blir i ett sådant samhälle lägre än vad det skulle ha varit på en pluralistisk religiös "marknad" - såvida inte lagstiftning eller den sociala kontrollen i samhället tvingar alla att deltaga $i$ exempelvis gudstjänster, oavsett om de själva vill det eller inte. Om en latent efterfrågan däremot skulle saknas, hjälper det givetvis inte att öka utbudet. Människor deltar inte i en verksamhet enbart därför att den finns, lika litet som de köper en vara enbart därför att den finns att köpa. Om en ny produkt skall kunna säljas eller en ny verksamhet skall kunna samla deltagare, måste det också finnas en potentiell eller latent efterfrågan på produkten eller verksamheten.

En central fråga i försöken att finna förklaringar till skillnaderna mellan Europa och USA i fråga om religiös utveckling har varit vilka effekter som religiös pluralism eller frånvaro av religiös pluralism kan väntas ha på religiöst deltagande. En av förklaringarna till religionens starka ställning i USA har sålunda ansetts vara att man där sedan länge haft en hög grad av religiös pluralism, dvs. ett stort antal kyrkosamfund, medan man i de europeiska länderna ofta haft en låg grad av pluralism (Finke \& Stark

Eva M Hamberg: Religiösa marknadsstrukturer, religiös... 
1992). I många länder i Europa har man haft en situation som liknat monopol eller oligopol: ett - eller i vissa fall två - kyrkosamfund har varit starkt dominerande och haft en stor andel av befolkningen som medlemmar. Ofta har dessa kyrkor också haft en av staten gynnad ställning.

En hög grad av religiös pluralism kan väntas leda till ett ökat religiöst deltagande av flera skäl. Pluralismen ger människor ökade möjligheter att finna samfund och gudstjänstformer som svarar mot deras religiösa behov och önskemål, och sannolikheten för att det skall finnas en latent efterfrågan som inte tillgodoses blir därigenom mindre. Dessutom kan konkurrensen mellan olika samfund förväntas leda till att kvaliteten på utbudet höjs. Sålunda kan exempelvis samfund där gudstjänsterna kännetecknas av bristande engagemang från de anställdas sida räkna med att förlora medlemmar till samfund där gudstjänsterna upplevs vara av högre kvalitet, och samfund där de anställdas trovärdighet inte uppfattas vara hög, kan räkna med att förlora medlemmar till samfund där de anställda upplevs ha högre trovärdighet (se nedan). På en pluralistisk religiös marknad kan konkurrensen mellan kyrkorna därför väntas leda till att samfunden ställer högre krav på djupt engagemang och personlig trovärdighet vid rekryteringen av präster och övriga anställda än vad kyrkor, som har en starkt dominerande position i ett samhälle, behöver göra.

Det bör påpekas att man i ett längre tidsperspektiv kan räkna med en växelverkan mellan utbud och efterfrågan. I ett samhälle där det religiösa utbudet inte motsvarar den latenta efterfrågan och där det religiösa deltagandet därför sjunkit till en låg nivå, tenderar nämligen den religiösa socialisationen att bli ineffektiv (Stark \& Finke 2000). Om föräldrarna inte deltar i gudstjänster, kommer som regel inte heller barnen att göra det, vilket får till följd att allt färre människor tillägnar sig kunskaper om religionen. I stället kommer många att utveckla sina egna religiösa trosföreställningar, som därmed blir individuellt präglade och varierande mellan olika personer. I ett sådant samhälle blir också andelen av befolkningen som har en religiös tro av något slag, betydligt högre än andelen, som deltar i någon form av organiserad religiös verksamhet. Rodney Stark och Roger Finke menar att en utveckling av detta slag är karakteristisk för länder, där ett visst samfund har en starkt dominerande ställning, och där alltså graden av religiös pluralism på organisationsnivå är låg. Sådana samhällen kännetecknas enligt Stark och Finke i allmänhet av lågt gudstjänstdeltagande och ineffektiv religiös socialisation, inte bara på grund av att de religiösa valmöjligheterna där är begränsade, utan också på grund av att samfund som har en starkt dominerande ställning tenderar att ha mindre engagerade medlemmar och anställda. Om graden av pluralism på den religiösa "marknaden« är låg, kan detta alltså leda till att man får en utveckling, där efterfrågan på det existerande utbudet successivt sjunker alltmer.

\section{Skiljer sig religiösa "marknader"fràn andra marknadstyper?}

Att fri konkurrens anses kunna påverka 
kyrkornas verksamhet på ett sådant sätt att den kyrkligt aktiva andelen av befolkningen ökar är en uppfattning som numera företräds av åtskilliga religionssociologer, inte minst i USA. Detta innebär dock knappast att företrädare för denna uppfattning skulle mena att det inte finns väsentliga skillnader mellan det utbud som erbjuds av kyrkorna och det utbud som exempelvis tandkrämsproducenter och biltillverkare står för. Tvärtom har man framhållit att just den specifika karaktären av kyrkornas "produkt» medför att "marknaden» i dessa fall fungerar på ett sätt som i viktiga avseenden skiljer sig från exempelvis marknaden för tandkräm eller bilar.

Sålunda får exempelvis frågan om trovärdighet en långt mer avgörande vikt $\mathrm{i}$ religiösa sammanhang än då det gäller "produkter" vilkas kvalitet är mer möjliga för potentiella kunder att kontrollera. Den som exempelvis köper ett hus, en bil eller en resa har ofta möjligheter både att i förväg kontrollera varans kvalitet och att $i$ efterhand begära kompensation om varan inte skulle uppfylla de löften som försäljaren givit. Den potentiella köparen har dessutom ofta möjlighet att få information om andra kunders erfarenheter av t.ex. ett visst bilmärke. Då det gäller religiösa organisationer ter sig emellertid saken annorlunda: någon motsvarande kontroll av tillförlitligheten i ett religiöst budskap, exempelvis sanningshalten i en religiös lära om vad som sker efter döden, låter sig av naturliga skäl inte göras. Detta får till följd att den religiösa förkunnarens eller "försäljarens« roll blir väsentligt annorlunda än vad som gäller på mer ordinära marknader: förkunnaren själv blir den som måste ikläda sig rollen som garant för det budskap som förkunnas, och hans eller hennes personliga trovärdighet får därför en helt avgörande betydelse för hur budskapet mottas. Detta får exempelvis till följd att en diskrepans mellan lära och liv får en förödande effekt för trovärdigheten hos en religiös organisation. Konsumenter kan kanske välja att köpa bilar eller hus av försäljare som de inte uppfattar ha någon hög grad av personlig trovärdighet, om de vet att det finns garantier och reklamationsrätt. När det gäller en religiös organisation blir däremot frågan om trovärdighet central.

Den vikt som den personliga trovärdigheten hos företrädare för kyrkor eller andra religiösa organisationer har, innebär också att lönenivåerna för de anställda kan påverka människors förtroende för budskapet. Ett företag som t.ex. säljer hus, bilar eller resor förlorar knappast i trovärdighet om de anställda har höga löner. Tvärtom kan det kanske uppfattas som tecken på att de produkter som man säljer är av god kvalitet och att verksamheten därför är framgångsrik, så att man har råd att betala sina anställda goda löner (även om misstankar om att försäljare har provision på sin försäljning nog kan tänkas minska konsumenternas förtroende för dem). När det gäller kyrkor eller andra religiösa organisationer förhåller det sig däremot annorlunda. Om exempelvis präster har höga löner, leder detta knappast till att människors övertygelse om sanningshalten i kyrkans förkunnelse ökar. Tvärtom kan det leda till misstankar om att prästerna själva egentligen inte tror på budskapet utan ser sitt yrke som ett sätt att försörja sig. Om präster

Eva M Hamberg: Religiösa marknadsstrukturer, religiös... 
däremot har löner, som är lägre än vad de skulle kunna räkna med i annan yrkesverksamhet, kan de knappast misstänkas för att ha valt sitt arbete av materiella skäl och deras personliga trovärdighet som garanter för budskapet förstärks. När det gäller kyrkor och andra religiösa organisationer kan man därför räkna med att tilltron till budskapet står i omvänd proportion till de materiella fördelar som de anställda uppfattas ha av sin verksamhet (Stark 1996 s. 174).

Även i andra avseenden finns skillnader mellan religiösa "marknader» och mer ordinära marknader. Ett företag, som upptäcker att dess produkt inte efterfrågas $\mathrm{i}$ tillräckligt stor utsträckning för att verksamheten skall vara lönsam, kan välja att förändra produkten efter kundernas önskemål eller övergå till att producera andra produkter som det finns större efterfrågan på. För företaget blir lönsamheten det avgörande kriteriet; att exempelvis av ideologiska skäl fortsätta att tillverka en produkt som endast få människor efterfrågar och som därför går med ekonomisk förlust, är knappast möjligt eller önskvärt. När det gäller kyrkor och andra religiösa organisationer är däremot möjligheterna att anpassa utbudet till efterfrågan begränsade. En kyrka som räknar med att dess verksamhet grundas på ett gudomligt uppdrag kan knappast förändra det ideologiska innehållet i verksamheten på ett genomgripande sätt utan att riskera att förlora sin identitet. Den religiösa "marknaden" skiljer sig därför i vissa betydelsefulla avseenden från marknaden för konsumtionsvaror.

\section{Antagandet att människors handlande bestäms av rationella val}

En av de frågor som har diskuterats i debatten om religiösa marknadsstrukturer och religiös pluralism är om det är rimligt att anta att människor agerar rationellt i religiösa sammanhang, exempelvis vid valet att tillhöra eller inte tillhöra ett kyrkosamfund, och vissa forskare har hävdat att man inte kan anta detta. Kritiken mot antaganden att människor agerar rationellt förefaller bland annat bero på att man uppfattar rationalitet som liktydigt med ekonomisk vinstmaximering. Man tror därför att de forskare, som menar att människor kan förväntas agera rationellt, skulle ha uppfattningen att människor enbart styrs av ekonomiska intressen.

Att ett visst handlande skulle kunna betecknas som rationellt endast om det leder till ett gynnsamt ekonomiskt resultat för individen bygger emellertid på den underförstådda förutsättningen att människors mål i första hand är att tillgodose de egna ekonomiska intressena. Handlingssätt, som inte får gynnsamma ekonomiska konsekvenser för individen själv, uppfattas därmed som irrationella; en person som Moder Teresa skulle utifrån en sådan förutsättning exempelvis ses som irrationell. Missförståndet ligger i antagandet att (alla) människor i första hand prioriterar sina egna ekonomiska intressen och att ett rationellt agerande därmed måste vara liktydigt med ett för individen ur strikt ekonomisk synpunkt fördelaktigt agerande. Vad som för en viss person är ett rationellt handlande beror emellertid av många fakto- 
rer, däribland personens egna värderingar. Utifrån de värderingar som Moder Teresa anslöt sig till, framstår sålunda hennes val av levnadssätt som i hög grad rationellt. Om ett agerande är rationellt eller inte kan bara bestämmas utifrån den enskilda individens preferenser, tillgång till information och faktiska möjligheter att i en given situation förverkliga sina mål.

Antagandet att människor beter sig rationellt är i själva verket en förutsättning för att individers handlande överhuvudtaget skall kunna förstås eller förutsägas. Inom samhällsvetenskaplig forskning är detta antagande en nödvändig förutsättning för att skeenden skall kunna framstå som begripliga och i viss mån möjliga att förutse. De amerikanska forskarna Rodney Stark och Roger Finke menar att antagandet om rationalitet inte skall uppfattas som en teori, utan i stället utgör en nödvändig utgångspunkt för teoribildningar som gäller människors handlande (Stark \& Finke 2000 s. 41).

Även i vardagslivet utgör detta antagande en implicit förutsättning för att interaktion mellan människor överhuvudtaget skall vara möjlig. Människor har visserligen olika preferenser, men i vissa avseenden är preferenserna så lika att det finns möjligheter till generaliseringar. Det är t.ex. inte en tillfällighet att man i dagligvaruhandeln ofta kan se skyltar med texten "Tag tre, betala för två», medan man torde ha svårt att hitta en skylt med uppmaningen »Tag två, betala för tre«. Att det förhåller sig så, illustrerar att man i det dagliga livet faktiskt tar för givet, inte bara att människor handlar rationellt, utan även att de reagerar på ekonomiska incitament på ett sätt som i viss utsträckning är förutsägbart: om människor får välja mellan att betala ett lägre eller ett högre pris för en viss vara, föredrar de normalt det lägre priset. Detta innebär emellertid inte att människor i alla valsituationer styrs av ekonomiska intressen; i många situationer blir i stället andra kriterier utslagsgivande. Att en person väljer rationellt kan i många fall innebära att valet leder till ett resultat som är ekonomiskt gynnsamt för individen, men det behöver inte göra det. Andra kriterier än de ekonomiska kan vara avgörande.

\section{Effekterna avökad religiös pluralism kan variera beroende på olika omständigheter}

En fråga som inte tillräckligt uppmärksammats i forskningsdebatten om religiös pluralism är att en ökad pluralism kan väntas få olika effekt beroende på vilken nivå ökningen sker från. Om ett samhälle som tidigare varit religiöst homogent blir mer pluralistiskt är det inte otänkbart att det religiösa deltagandet $\mathrm{i}$ ett initialt skede minskar. En orsak till detta skulle kunna vara att religionen inte på samma sätt som tidigare skulle uppfattas som självklar. Med en kunskapssociologisk terminologi kan detta uttryckas så att uppkomsten av konkurrerande världsbilder skulle kunna undergräva religionens plausibilitetsstruktur. En annan orsak skulle kunna vara att individerna inte längre utsätts för lika starkt juridiskt och/eller socialt tryck att vara religiöst aktiva. Människor som tidigare deltagit i gudstjänster till följd av 
samhällets krav eller omgivningens förväntningar skulle få ökad frihet att avstå från religionsutövning.

Att förändringar i det omgivande samhällets krav på religionsutövning kan påverka människors religiösa aktivitet stöds bland annat av forskning om religiös förändring i samband med internationell migration. Då människor flyttar från en miljö, där religionen är en självklar del av livet, till en miljö, där religionsutövning mer är en fråga om individens eget val, kan förändringar i religiöst avseende äga rum. Ett exempel på detta ges i en studie av forskaren Werner Schiffauer, som har studerat dels den muslimska befolkningen i en by i Turkiet, dels utvandrare från samma by som var bosatta i Tyskland, och jämfört de båda grupperna (Schiffauer 1990). I den turkiska byn fungerade religionsutövningen som uttryck för samhörighet med det omgivande samhället och de yttre formella aspekterna av religionen betonades mycket starkt: tonvikten låg mer på att inför omgivningen visa att den grupp man tillhörde fullgjorde sina religiösa förpliktelser än på gruppmedlemmarnas inre attityder. Den grupp som var bosatt i Tyskland kännetecknades av mycket större individuella skillnader i fråga om religiös praxis. Den frihet att välja om man ville utöva religionen eller inte, som fanns i invandringslandet, ledde till att individens religiösa ansvar betonades och att religionsutövningen fick en mer renodlat religiös motivering. Som en följd av detta kom religionsutövningen att variera starkt mellan olika individer. För somliga fick religionen mindre betydelse än den haft $\mathrm{i}$ hemlandet, för andra blev religionen i stället mer betydelsefull. En utveck- ling av detta slag kan väntas inträffa, inte bara i samband med migration, utan också i samband med att religiös pluralism utvecklas i ett samhälle som tidigare varit religiöst homogent. Den ökade friheten att själv avgöra om man vill deltaga i religionsutövning eller inte kan leda till att andelen som är religiöst aktiva sjunker.

Om ett samhälle redan kännetecknas av en viss religiös pluralism förefaller det emellertid mindre troligt att en ytterligare ökning av pluralismen skulle undergräva religionens plausibilitetsstruktur och därigenom leda till minskat religiöst deltagande. I ett sådant läge skulle man i stället kunna vänta att pluralismens positiva effekter på den religiösa aktiviteten skulle överväga. Sannolikt skulle detta emellertid endast gälla till en viss gräns: om ett samhälle redan kännetecknas av en hög grad av pluralism, förefaller det mindre troligt att en ytterligare ökning skulle ha någon nämnvärd inverkan på det religiösa deltagandet. Effekterna av en ökad religiös pluralism kan alltså förväntas bli olika beroende på vilket utgångsläge som ökningen sker från. Detta skulle kunna vara en förklaring till att ett positivt samband mellan ökad pluralism och ökat religiöst deltagande har kunnat påvisas i flera studier av den religiösa "marknaden" i Sverige (Hamberg \& Pettersson 1994, 1997, 2002, Pettersson 2001, Pettersson \& Hamberg 1997).

Dagens svenska samhälle präglas både av att det religiösa deltagandet är mycket lågt och av att graden av religiös pluralism är låg, jämfört med många andra länder. Svenska kyrkan hade så sent som vid mitten av 1900-talet nära nog en monopolställning på den svenska religiösa »markna- 
den". Först i och med 1951 års religionsfrihetslag blev det tillåtet att utträda ur Svenska kyrkan utan att samtidigt inträda i ett annat av staten godkänt samfund. De kvardröjande effekterna av detta är ännu mycket tydliga, trots den skilsmässa mellan stat och kyrka som genomfördes år 2000. Svenska kyrkan har fortfarande mer än 70 procent av befolkningen som medlemmar och har därmed en starkt dominerande ställning på den religiösa "marknaden«. Samtidigt är Sverige ett av de allra mest sekulariserade länderna i västvärlden. Bara en knapp tiondel av befolkningen deltar regelbundet i gudstjänster och bland Svenska kyrkans medlemmar är andelen ännu lägre (Hamberg 2003, se även Thorleif Petterssons artikel i detta nummer av Socialvetenskaplig Tidskrift). I ett samhälle som kännetecknas av så låg grad av religiös pluralism, är det inte osannolikt att även små ökningar av pluralism i det religiösa utbudet kan få betydelse för gudstjänstdeltagandet. Det är dessutom troligt att det sedan länge mycket låga gudstjänstdeltagandet och den därmed sammanhängande ineffektiva religiösa socialisationen har medfört att den religiösa efterfrågan $i$ Sverige är mindre homogen än vad den är i samhällen där den religiösa socialisationen fungerat mer effektivt (se ovan). Även detta kan tänkas medföra att ett mer varierat religiöst utbud får större effekt under svenska förhållanden än i samhällen där den religiösa efterfrågan är mer homogen. Effekterna av ökad variation i utbudet kan nämligen väntas bli större om det finns en stor variation i efterfrågan (Hamberg \& Pettersson 2002).

Sambandet mellan religiös pluralism och religiöst deltagande kan alltså förväntas se olika ut i olika samhällen och under olika skeden av en historisk utveckling. Att utbudet på en religiös "marknad» är en av de faktorer som kan ha en avgörande betydelse för det religiösa deltagandet i ett samhälle tyder dock åtskilliga empiriska studier på. Det bör dock betonas att även om det finns starka skäl att antaga att religiös pluralism befrämjar den religiösa aktiviteten i ett samhälle, innebär detta inte att graden av pluralism skulle vara den enda faktor som har betydelse i sammanhanget. Det innebär inte heller att ökad religiös pluralism alltid skulle leda till att den religiösa aktiviteten ökar. Förhållandet mellan utbud och efterfrågan på religiösa "marknader" påverkas sannolikt av en rad olika faktorer i ett komplext samspel. Religionens ställning i ett samhälle kan inte förklaras av en enda faktor, utan man måste räkna med att flera olika faktorer påverkar utvecklingen.

Det finns dessutom goda skäl att antaga att olika aspekter av ett samhälles modernisering kan ha olika, och delvis motsatta, effekter på den kyrkoorienterade religionens utveckling. Det finns exempelvis forskning som tyder på att ett ökat välstånd kan leda till att den traditionella religionens betydelse avtar. Religionssociologen Thorleif Pettersson har pekat på detta i en diskussion av vilken betydelse å ena sidan ett ökad välstånd och å andra sidan en ökad religiös pluralism kan ha för den traditionella kyrkoorienterade religionens utveckling. Pettersson menar att den förstnämnda faktorn undergräver den kyrkoorienterade religionens ställning, medan den senare faktorn befrämjar den (Pettersson 2006, se även Thorleif Petterssons arti-

Eva M Hamberg: Religiösa marknadsstrukturer, religiös.. 
kel i detta nummer av Socialvetenskaplig Tidskrift).

Det är i detta sammanhang också viktigt att framhålla att om man med sekularisering menar den process, som har inneburit att de kristna kyrkorna förlorat en stor del av sitt tidigare samhällsinflytande och att en allt lägre andel av befolkningen omfattar en traditionell kristen tro och deltar i gudstjänster, så innebär sekularisering inte med nödvändighet att alla former av religion förlorar mark. Tvärtom finns det mycket som talar för att andra former av religion eller andlighet vinner ökad betydelse i sekulariseringens spår, då den traditionella religionens tillbakagång leder till att många människor i stället utvecklar sina egna religiösa trosföreställningar. Som exempel på detta kan nämnas sådana former av individuell religion som brukar betecknas som "privatreligion", "New Age» eller "nyandlighet«. Den traditionella kyrkoorienterade religionens tillbakagång har alltså i viss utsträckning medfört att religion eller andlighet utanför kyrkorna i stället har vunnit mark (Stark \& Finke 2000, Stark et al. 2005, Hamberg 2008).

Om man räknar med att den låga graden av religiös pluralism i många europeiska länder, inte minst Sverige, har varit en starkt bidragande orsak till den långt gångna sekulariseringen, kan en intressant fråga för den religionsvetenskapliga forskningen bli att studera om den traditionella kyrkoorienterade religionens roll på längre sikt påverkas av den ökade religiösa pluralism som invandringen medför. Det religiösa landskapet i många av de västeuropeiska länderna har redan nu förändrats genom invandringen och på några decen- niers sikt kommer förändringarna sannolikt att vara ännu mer påtagliga. Samtidigt är det viktigt att påpeka att en betydande del av de immigranter som lever i de västeuropeiska länderna inte är religiöst engagerade och att många av dem tagit avstånd från den religion som präglade deras hemländer. Även när det gäller de invandrare som är religiöst aktiva är det en öppen fråga i vilken utsträckning deras religiösa engagemang och praxis kan komma att förändras av kontakterna med de sekulariserade europeiska samhällena. Empiriska studier av religiös förändring i samband med internationell migration har visat att migration kan påverka invandrares religiositet på olika sätt (Hamberg 1999). I vissa fall sker ingen större förändring i religiöst avseende. I andra fall kan religionens betydelse för immigranterna minska eller upphöra under livet i det nya landet. I åter andra fall kan migrationen i stället leda till att det religiösa engagemanget ökar. Dessutom kan i vissa fall mer radikala förändringar ske, som innebär att den religiösa identiteten påverkas på ett mer genomgripande sätt. Detta gäller till exempel då invandrare engagerar sig i religiösa rörelser av sektkaraktär. Det är således inte möjligt att förutsäga hur de europeiska länderna kan komma att förändras i religiöst avseende i samband med immigrationen, men en hypotes kan vara att migrationen kommer att leda till en ökad religiös pluralism och därmed i ett längre tidsperspektiv kan komma att bidraga till att de religiösa marknadsstrukturerna förändras. Förändringar av detta slag brukar ske långsamt (se Finke \& Stark 1992), men det kan inte uteslutas att migrationen kan bli en faktor som kan 
komma att stärka den traditionella, institutionellt orienterade, religionens ställning i Sverige och andra europeiska länder.

\section{Sekulariseringens samhällskonsekvenser - ett exempel}

Det svenska samhället präglas alltså av en långt gången sekulariseringsprocess, i den meningen att de kristna kyrkorna har förlorat en stor del av sitt tidigare inflytande och i den meningen att bara en minoritet av befolkningen numera omfattar en traditionell kristen tro och regelbundet deltar i kyrkornas gudstjänster. Frågor om sekulariseringens orsaker och följder är ur religionssociologisk synpunkt av stort intresse och har blivit föremål för omfattande uppmärksamhet från forskares sida. En fråga som i detta sammanhang också kan vara av intresse är emellertid vilka samhällskonsekvenser som det svenska samhällets sekularisering kan tänkas ha på olika områden. I denna artikel finns naturligtvis inte utrymme att behandla den frågan mer ingående, men jag skall avslutningsvis, som ett exempel på sådana konsekvenser, mycket kortfattat diskutera en aspekt av hur sekulariseringen påverkar det svenska samhället, nämligen sekulariseringens betydelse för Sverige som invandringsland.

Forskare och andra har inte sällan påpekat att det hos många svenskar idag finns en omedvetenhet om eller brist på förståelse för den roll som religionen kan spela i människors liv. Vissa forskare har till och med menat att det svenska samhället skulle kännetecknas av vad man har betecknat som "religionsblindhet" (se Hanson 2006). Det är rimligt att antaga att denna bristande förståelse hos många svenskar för vad religion normalt innebär sammanhänger med att Sverige är ett av de länder i västvärlden där sekulariseringen har gått allra längst.

Den oförmåga, som kännetecknar många svenskar, att förstå den betydelse som religionen kan ha i människors liv kan bland annat få konsekvenser för invandrare och flyktingar som söker sig till Sverige. Den kan ses som en bidragande orsak till de speciella problem som ofta uppstår när invandrare och flyktingar från länder, där religionen har en självklar roll i människors liv, möter det sekulariserade svenska samhället. Inte minst de invandrare för vilka religionen spelar en central roll i livet, ger ibland uttryck för att man upplever det svenska samhällets sekularisering som ett problem. Sådana tankegångar kan exempelvis avspeglas i uttalanden som detta:

"Vi muslimer har inga direkta konflikter med Sverige som ett kristet land, men däremot med Sverige som ett sekulariserat och moderniserat land. Vår strävan efter kulturellt bevarande står $i$ motsats till den så kallade frihet som tillaiter allt. Men den friheten kommer inte från kristendomen, utan snarare från brist på kristendom " (Södling 1991 s. 40).

Det bör dock påpekas att sådana uppfattningar givetvis inte delas av alla invandrare från länder där islam är den dominerande religionen; för många framstår i stället 
det svenska samhällets sekularisering som något positivt.

Den bristande förståelsen för religioners roll och funktion, som många svenskar har, kan påverka relationerna mellan majoritetssamhället och invandrare eller asylsökande på flera sätt. Den har betydelse för hur människor från andra länder upplever det svenska samhället. Den har också betydelse för hur den svenska allmänheten uppfattar de invandrare som man ser som "religiösa" och hur man ser på deras religionsutövning. Den kan dessutom påverka kontakterna mellan myndigheter och enskilda personer från andra länder. Den syn på aktivt utövande av religion, som många svenskar har, kommer nämligen ibland också till uttryck i myndigheters ställningstaganden vid bedömningar av religionens betydelse i asylärenden. Detta förekommer exempelvis i ärenden som rör personer som, antingen i hemlandet eller under sin tid som asylsökande i Sverige, konverterat från islam till en annan religion, t.ex. kristendomen eller Jehovas vittnen. I det sekulariserade svenska samhället uppfattas religion oftast som något privat, något som individen kan ägna sig åt $\mathrm{i}$ hemmet men som inte behöver ta sig några synliga uttryck i vardagslivet och som därför enkelt kan döljas för omgivningen. Om man har en sådan syn på religion kan det vara svårt att förstå varför en person, som i hemlandet skulle utsättas för trakasserier eller förföljelse om hans eller hennes religionstillhörighet blev känd, inte på ett enkelt sätt skulle kunna lösa detta problem genom att hålla sin religion hemlig. Men ett sådant synsätt riskerar att leda till att exempelvis frågor om religion som skäl för asyl inte alltid får den djupgående prövning som skulle erfordras. ${ }^{2}$

Även i samband med muslimers kamp för att få bygga moskéer framstår "det faktum att Sverige är ett av världens mest sekulariserade länder med ringa förståelse för religion överhuvudtaget« som en viktig orsak till svårigheterna (Karlsson \& Svanberg 1995 s. 8). I de debatter som förts om muslimers rätt att bygga moskéer har visserligen kristna i vissa fall tagit strid mot moskéer. Detta har främst gällt vissa frikyrkliga debattörer, men ibland har också präster inom Svenska kyrkan hört till moskémotståndarna. ${ }^{3}$ I allmänhet har dock representanter för de kristna samfunden, både lokalt och på riksplanet, hört till dem som försvarat muslimernas rätt till gudstjänstlokaler (Karlsson \& Svanberg 1995). Mycket talar alltså för att inställningen till invandrare med annan religionstillhörighet ofta är mer positiv bland människor som själva aktivt utövar en religion än bland människor som saknar förståelse för religionens betydelse.

En ökad förståelse för den sociala och psykologiska funktion, som religionen kan ha för individer och grupper, skulle sannolikt bidra till att minska risken för främlingsfientliga attityder. Det som ofta tycks

2 Se även Lagerqvist Velos Roca, Annika, "Gränsbevakning med fiktiva mikroskop", Dagens Juridik, 2009-06-16 för en diskussion om detta.

3 Även kristna invandrare från Turkiet och Mellanöstern, som haft erfarenheter av religiösa konflikter i hemländerna, har ibland starkt motsatt sig moskébyggen med hänvisning till förföljelser och intolerans mot kristna i muslimska länder (Karlsson \& Svanberg 1995). 
väcka oförståelse och negativa reaktioner hos sekulariserade svenskar är nämligen den roll som religionen spelar i vardagslivet, exempelvis när det gäller klädsel och matvanor. En viktig aspekt i detta sammanhang är islams synlighet, något som illustreras av att det i debatterna om moskéer särskilt har varit tanken på minareter, som mött kompakt motstånd. Motståndet mot dessa har inte enbart gällt böneutrop, utan också att minareterna genom sin höjd skulle komma att utgöra ett störande inslag i gatubilden. "Det som skulle kunna ses som något positivt - moskén som symbol för muslimsk närvaro - sågs istället som något negativt eller rent provocerande« (Karlsson \& Svanberg 1995 s. 82). Det som av en del infödda svenskar upplevs som annorlunda och främmande, kan uppfattas som ännu mer hotande för den egna identiteten om det, förutom att vara annorlunda, också påminner om sin närvaro genom att utgöra en påtaglig del av den vardag man lever i. Att reaktioner av detta slag ofta har förekommit i samband med planerade moskébyggen sammanhänger antagligen till stor del med att förståelsen för att religionen faktiskt kan spela en central roll i människors liv är låg i det sekulariserade Sverige. Den långt gångna sekulariseringen får därmed praktiska konsekvenser för dagens mångreligiösa svenska samhälle. Frågor som gäller sekulariseringens orsaker och följder är därför inte enbart av vetenskapligt intresse; det är också frågor som i olika sammanhang har relevans för myndigheter och andra aktörer i samhället.

\section{Referenser}

Finke, R. \& Stark, R. (1992) The Churching of America, 1776-1990. Winners and Losers in Our Religious Economy. New Brunswick, NJ: Rutgers University Press.

Hamberg, E. M. (1999) „Migration and Religious Changer. In E. Helander (ed.) Religion and Social Transitions. Helsinki: Helsinki University Press.

Hamberg, E. M. (2003) "Christendom in Decline: the Swedish Caseu. In H. McLeod \& W. Ustorf (eds.) The Decline of Christendom in Western Europe, 1750-2000. Cambridge: Cambridge University Press.

Hamberg, E. M. (2008) „Unchurched Spirituality». In P. B. Clarke (ed.) The Oxford Handbook of the Sociology of Religion. Oxford: Oxford University Press.

Hamberg, E. M. \& Pettersson, T. (1994) »The Religious Market: Denominational Competition and Religious Participation in Contemporary
Sweden". Journal for the Scientific Study of Religion, vol. 33, no 3, pp. 205-216.

Hamberg, E. M. \& Pettersson, T. (1997) "Shortterm Changes in Religious Supply and Church Attendance in Contemporary Sweden". Research in the Social Scientific Study of Religion, vol. 8, pp. 35-51.

Hamberg, E. M. \& Pettersson, T. (2002) »Religious Markets: Supply, Demand, and Rational Choices». In T. G. Jelen (ed.) Sacred Markets, Sacred Canopies: Essays on Religious Markets and Religious Pluralism. Lanham, USA: Rowman \& Littlefield.

Hanson, B. (2006) "Begreppet religionsblindhet». I S. A. Flodell (red.) Religionsblindhet. Stockholm: Stiftelsen Sverige och kristen tro.

Karlsson, P. \& Svanberg, I. (1995) Moskéer i Sverige. En religionsetnologisk studie $i$ intolerans och administrativ vanmakt. Uppsala: Svenska kyrkans forskningsråd.

Eva M Hamberg: Religiösa marknadsstrukturer, religiös.. 
Lagerqvist Velos Roca, A. (2009) „Gränsbevakning med fiktiva mikroskop». Dagens Juridik, 200906-16.

Pettersson, T. (2001) „Många eller få? - Drygt en halv miljon kyrkobesök under ett veckoslutu. I M. Skog (red.) Det religiösa Sverige. Gudstiänstoch andaktsliv under ett veckoslut kring millennieskiftet. Örebro: Libris.

Pettersson, T. (2006) „Religion in Contemporary Society: Eroded by Human Well-being, Supported by Cultural Diversity". Comparative Sociology, vol. 5, no 2-3, pp. 231-257.

Pettersson, T. (2009) „Religion och samhällspraktik. En jämförande analys av det sekulariserade Sverige». Socialvetenskaplig Tidskrift, årg 16, nr 3-4, s. 233-264.

Pettersson, T. \& Hamberg, E. M. (1997) „Denominational Pluralism and Church Membership in Contemporary Sweden. A Longitudinal Study of the Period 1974-1995«. Journal of Empirical Theology, vol. 10, no 2, pp. 61-78.
Schiffauer, W. (1990) "Migration and Religiousnessu. In T. Gerholm \& Y. G. Lithman (eds.) The New Islamic Presence in Western Europe. London: Mansell Publishing Ltd.

Stark, R. (1996) The Rise of Christianity. A Sociologist Reconsiders History. Princeton: Princeton University Press.

Stark, R. \& Finke, R. (2000) Acts of Faith. Explaining the Human Side of Religion. Berkeley, Los Angeles och London: University of California Press.

Stark R., Hamberg E. \& Miller A. (2005) „Exploring Spirituality and Unchurched Religions in America, Sweden, and Japan". Journal of Contemporary Religion, vol. 20, no 1, pp. 3-23.

Stark, R. \& Iannaccone, L. R. (1994) "A SupplySide Reinterpretation of the 'Secularization' of Europe». Journal for the Scientific Study of Religion, vol. 33, no 3, pp. 230-252.

Södling, M. (1991) Religioner möts $i$ Sverige. Åtta röster om tro. Stockholm: Verbum Förlag.

\section{Summary}

\section{Religious market structures, religious pluralism and processes of secularization}

Compared to most other countries in the world, many of the European countries are highly secularized in the sense that only low shares of the population now adhere to the traditional church-oriented religion. In particular, Sweden is often described as one of the most secularized countries in the world.

Sociologists of religion differ in their assumptions about the causes of the secularization processes that have led to the contemporary European situation, and several competing theories have been advanced. This paper discusses the impact of religi- ous market structures as factors behind secularization processes. In particular the impact of religious pluralism is discussed, and it is argued that a low degree of religious pluralism may be an important factor in this context.

The paper concludes with a brief discussion of an example of the social consequences of secularization in Sweden, namely the particular problems that immigrants and refugees sometimes face as a result of the low importance ascribed to religion in Swedish society. 